\title{
INVENTED TRADITION AND THE NEW REGIONALISM. THE REVIVAL OF PASTORALISM IN OCHOTNICA GÓRNA (POLISH CARPATHIAN VILLAGE)
}

\author{
EWA NOWICKA
}

\begin{abstract}
The article is based on anthropological fieldwork in Ochotnica Górna, a village belonging to Podhale region (southern Poland). The study was focused on the revival of transhumance - the type of pastoralism, characteristic for Valachian villages of the entire range of Carpathians.

The transhumance has been destroyed by global economic transformation in Poland. Recently it is revived on the new ideological basis connected with the idea of Carpathian and Valachian regionalism.
\end{abstract}

Ewa Nowicka, professor, Collegium Civitas, Plac Defilad 1, 00-901 Warsaw, Poland, phone: (48)695440431, e-mail: ewanowickarusek@gmail.com

Keywords: pastoralism, invented tradition valachians, Ochotnica Górna.

DOI: http://dx.doi.org/10.14746/bp.2015.22.11

\section{INTRODUCTION}

Ochotnica is the longest village in Poland $-27 \mathrm{~km}$ : it fills a large valley between two forested mountain ranges with side subsidiary valleys. The villages history began in 1416, during the rule of the Polish king Władysław Jagiełło, according to Ius Valachicum ${ }^{1}$. Today, the inhabitants of Ochotnica are proud of this long history; the persons most engaged in the Podhalan regional movement, members of the Association of Podhalans, underline that Ochotnica was the first, and even the only Polish Podhalan village founded on Wallachian Right.

The article is based on 6 years of systematic research between 2007-2014 conducted in Ochotnica Górna, a Podhalan village in the Gorce Mountains. I focus on contemporary developments of the present day reconstruction of pastoralism, the process based on "salasz" customs and social structure in the Gorce region.

In the book by Paul Rabinow about Morocco $^{2}$ we find a statement which can be considered as a direction through which we can understand the cultural situation of today's Ochotnica, namely that "Tradition is a moving image of the past"3. Rabinow's observation on Marrocan people forty years ago can be applied to today's Ochotnica:

\footnotetext{
${ }^{1}$ Jawor, Grzegorz, Osady prawa woloskiego i ich mieszkańcy na Rusi Czerwonej w późnym średniowieczu, (Lublin: Wydawnictwo UMCS, 2004).

${ }^{2}$ Rabinow, Paul, Reflections on fieldwork in Morocco, (Oakland: Univ of California Press, 2007).

${ }^{3}$ Rabinow, Paul and Bennett, Gaymon, "A Diagnosticof Equipmental Platforms," ARC Working Paper, No. 9, 2007, 10.
} 
be applied to today's Ochotnica. He said "The Morrocans with whom I stayed in the mountain village were most certainly trying to find a way to reconstruct their own heritage and the sacred power deposited in it. They created their contemporary relations using new and old elements, but they consistently tried to accept them rather as a reproduction and not as an emergence of new elements. Rabinow further notes that, "if the dominant symbols cease to give meaning to the past and they are not being replaced, it is when the process of alienation begins".

When we intend to investigate the identity of the mountain people, their traditions preserved in the present form in the Podhalan village, a reference to the conception of invented tradition by Eric Hobsbawm seems also very attractive. Hobsbawm explains that the notions he is interested in encompass "both the truly made up traditions, built up from scratch and officially implemented, as well as those which emerge in a short well defined period of time in a way which is more difficult to 'retrace"'4. The author underlines the artificial process of creating cultural phenomena that we consider immemorial. He notices their volatility, newness, and the need to anchor them in the past, and seek ties with the past. It seems that the quality of being immemorial constitutes special value ascribed to cultural content.

Following my theoretical assumptions grounded on the distinction between two types of relations - based on custom and deriving from ideology, is conceptions we owe to Stanisław Ossowski ${ }^{5}$ I ascribe to the ideas of Eric Hobsbawm who aptly distinguishes between customs safeguarding the continuity of culture in traditional societies and the "invented tradition". Hobsbawm and his colleagues point to invented traditions namely elements of culture considered immemorial but which in fact were "made up" or came into being in now unknown circumstances. However, as he claims, "From our point of view it is more interesting to look at the way old materials are used to cre-

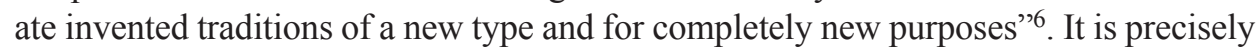
this conceptualization of "tradition" that I consider appropriate to analyse the highland culture more specifically the pastoral tradition in the village of Ochotnica Górna. My focus is on the return to the traditional Valachian type of transhumant pastoral economy, its ideological background, the reality in which the plans are put into practice and the belief in the Valachian community of the Carpathian shepherds.

\section{PASTORALISM AND THE NATURAL MOUNTAIN ENVIRONMENT AS VALUE}

Historically, in the times when the economy was close to nature, the natural environment determined the specific economic solutions, which in practice meant that a particular type of economy developed in a particular area. In other words, histori-

\footnotetext{
${ }^{4}$ Hobsbawm, Eric, Introduction, [in:] Ranger, Terence O., Hobsbawm, E., eds. The invention of tradition. (Cambridge: Cambridge University Press, 1983), 9.

${ }^{5}$ Ossowski, Stanisław, Analiza socjologiczna pojęcia ojczyzny,(Łódź: Myśl współczesna, 1946).

${ }^{6}$ Hobsbawm, Introduction..., 14.
} 
cally the environment predetermined the type of economy. Today, the connection between the economy and the type of environment has become much looser, yet both domains cannot be perceived as independent of each other. In fact, at present, a reversed kind of relationship between the environment and economy emerges. That is to say, social consciousness has discovered the autotelic value of a natural habitat for people and the ideals of "sustainable development" and ecological systems have been formulated. It is in this context that prosperity, the wellbeing and the decent life of people are considered. The natural environment is no longer seen as a resource to make use of and at present we are witnessing conservationist movements to preserve some features of the environment and the way it is organized. Consequently there are two current directions: on the one hand protecting the environment itself has become the main objective, and on the other hand, the protection extends to social structures which are closely connected with the protected elements of natural habitats.

In the mountain regions, farming had a limited opportunities to develop, however vast grassy areas located high up, the so-called high mountain meadows (open spaces without trees) could be used as ready-made pastures. These natural areas were further extended by clearing forests and burning trees to create man-made pastures. This policy was implemented by the Wallachian settlers who lived in forested mountain areas which were not used by people, among others in Gorce (this is confirmed by the geographical name of Gorce which is etymologically related to the meaning of 'burning out'; the same connection refers to the name of 'Ochotnica').

The pastoral economy was very lucrative for the owners of the pastures. From the early $15^{\text {th }}$ century the settlement of shepherds on the Wallachian Right started to spread over the area of the Western Carpathians. The Wallachian Right granted many privileges to the shepherds and was connected with a unique social structure adjusted to their work during the grazing season with a hut (Polish szalas) at the centre of their community.

Up to the present in the Carpathian Mountains, mostly in Greece, Albania, Macedonia, Serbia and Romania the so called transhumant pastoralism is still practised and involves the seasonal movement of sheep between the summer pastures and droving them for winter to the valleys clear of snow or to their village base. The social structure which was observed in the high pastures was different from the structure in the village and it was referred to as the hut structure. When from the beginning of the 15th century the shepherd community started to be settled in the area, which because of its location in the lower mountains did not have natural grassy areas to be used for grazing, pastures started to be created by cutting down forests. As a result vast clearings appeared on huge areas from the Bieszczady Mountains to the Moravian Gate, and from the Low Beskids Mountains to the Silesian Beskids. These open areas give a distinctive feature to the Beskids landscape and make it especially attractive for tourism. Recently, however these clearings are gradually becoming overgrown by forests, which on the one hand restores a more primeval landscape of the Beskids mountain ranges, but on the other hand, it lowers the attractiveness of the region for tourism as open viewing areas are being reduced. Also in Gorce the mixed nature of the land- 
scape including forested and cleared areas is disappearing. Furthermore, the progressive secondary succession of forests is also seen as a threat to the natural environment as some endemic species, which lived in the area because of the specific fertilizing effect of sheep being pastured on the clearings, are becoming extinct.

\section{THE DEMISE OF SHEEP GRAZING IN THE WESTERN CARPATHIANS}

At present a saying so well known in the Podhale region: "Who has sheep, has it all"7 has lost its meaning. Nevertheless, it remains as a document of the past hierarchy of importance which reflected the pastoral lifestyle, the dependence of one's wellbeing and the social rules in the community. From the mid-20 ${ }^{\text {th }}$ century in the Polish Carpathian Mountains primary transhumant pastoral culture has gradually become degraded or even altogether disappeared. The major reasons which resulted in the demise of the pastoral tradition in the Beskids Mountains were brought about by civilization, and more specifically by economic changes. For a variety of reasons grazing sheep became unproductive and at the same time the local people faced new prospects including different types of farming, educational opportunities or migration to cities, or abroad in the search of more profitable employment. As lifestyles started to change quite quickly, pastoral tradition gradually lost its value. In 1980 in Ochotnica Górna there was still one working station for shepherds tending sheep in a large clearing (on the Magurki range) which had its traditional social structure. Soon afterwards this occupation became so unattractive that nobody wanted to continue such work. It seems that in this particular place the pastoral tradition was abandoned because of social and economic reasons. The fate of the pastoral tradition was slightly different in the Tatra Mountains. The grazing of sheep in the Tatra Mountains was eliminated by a directive to move sheep out of the mountains - known as the great redyk [Polish term meaning the exodus of sheep with shepherds to pastures]. First the sheep were moved to the Pieniny Mountains because of the overpopulation of flocks which did not have enough food and they also endangered the unique landscape of the Tatra Mountains by causing soil erosion. Still the mountain people from the Tatra Mountains region continued to demand the return of pastoral traditions to the mountains. Their demands increased in the early 1980's with the growing activity of the Solidarity movement. As a result of these demands in 1982 the grazing of the sheep was reinstated in the Tatra Mountains and it was called 'cultural grazing'; the name is to be regarded as symptomatic for the newly established form of sheep farming. The new form retains theoretically both the structure of the hut as well as the basic customs characteristic of the Wallachian Carpathian shepherds. However, there are also significant changes to the prototype and they include the institutionalization of the requirements addressed at people working on the pastures. These requirements are no longer rooted in the cus-

\footnotetext{
${ }^{7}$ Hobsbawm, Introduction..., p. 14.
} 
tom but in invented tradition, as Hobsbawm would put it. According to the new, and at the same time traditional manner of grazing sheep in the Tatra Mountains National Park, the head shepherd and his helpers are required to have a licence, to provide pastures for their sheep outside the National Park (during the winter with no vegetation) as well as they are required to wear clothes classified as regional and communicate with each other and with tourists in their highland dialect. The only breed of dog allowed on the pastures is the local Polish Tatra sheepdog. Also the number of sheep on high mountain pastures and on clearings has been limited in agreement with the Tatra National Park ${ }^{8}$

In recent years pastoralism has also been reinstated in a similar way in other mountain regions in Europe. Programmes which restore elements of the past type of pastoral farming are implemented in a 'top-down' manner and they strictly speaking support this form of grazing on Alpine highland pastures (cow grazing) and on the high mountain pastures and clearings in the Carpathian Mountains.

\section{RESTORATION OF PASTORAL FARMING IN OCHOTNICA GÓRNA}

Recently, in connection with the on-going process of secondary forest succession on clearings previously used as pastures, which is considered as detrimental to the natural environment, and in consequence also to the local inhabitants who to a certain degree rely on income from tourism, plans were made to restore pastoralism also in the Podhale area, including Gorce. Following talks with the socially most active inhabitants of Ochotnica, mainly members of the Podhalan Association, it appears that the projects are closely connected with the conservationist idea of preserving the highland culture so closely related to "Wallachian Carpathian pastoralism" in terms of the common source and development over many centuries.

From the point of view of my research interest, it is important that this move, which in principle aims at maintaining the equilibrium in the natural eco system of the environment is perceived by the local inhabitants of Podhalan villages as an activity for the benefit of the regional/ethnic culture. This attitude is present in the speeches delivered at the conference, which took place in Ochotnica Górna (6-7 August 2011 r.) and in the opinions reported by leaders of the Podhalan community in Ochotnica and other villages. Sheep grazing appears as an element of the Wallachian tradition which needs to be kept alive as a now endangered old culture. The presence of sheep grazing on the clearings is enumerated as a part of a larger whole, next to the regional highland dialect, regional clothing, highland folk music and dance, which is alto-

\footnotetext{
${ }^{8}$ Styrczula-Maśniak, Edward, Na szlaku wyrobów z mleka owczego, (in:) Kiereś M. (ed.) Pasterstwo w Karpatach. Tradycja a wspótczesność. Szkice (Warszawa: Centrum UNEP/GRID \& Grafikon, 2013) 163-171; Bukowski Marcin, Dynamika zarastania polan tatrzańskich, (in:) M. Guzik (ed.), Dlugookresowe zmiany w przyrodzie i użtkowaniu TPN (Zakopane: Wydawnictwa Tatrzańskiego Parku Narodowego, 2009), 15-32.
} 
gether called 'tradition', and sometimes more specifically - the Wallachian tradition of the Carpathian Mountains. These activities are at the same time supported by the European Union. The project "Sheep Plus" is an example of an organized and institutionalized programme focused on reinstating sheep grazing in the Beskids Mountains. According to its primary objectives, which have been publicized, the project is "an example of a practical implementation of active protection of the natural value of the mountain pastures and clearings belonging to the Silesian and Żywiec Beskids as well the xerothermic grasslands in the Kraków-Częstochowa Upland. The project aims to stop the secondary succession of forests by restoring a pastoral economy as well as to cultivate the cultural identity related to sheep farming, promote traditional folk culture and the development of handcraft and production of goods derived from sheep and goats" (WWW...). It seems that pastoralism is combined into one complex cluster together with cultural aims (maintaining the tradition, nurturing folk culture, local and regional cultural activity, upholding or even regenerating the specific identity of the local inhabitants) and also with economic objectives (development of such types of food production which can be obtained in the specific natural conditions effectively in terms of the economy). To achieve these objectives pastoralism becomes the central point in shaping the individual identity in the local community of the region. The geographical area of the region is in fact not marked out due to historical and cultural background but due to conditions in the natural habitat since the area of the KrakówCzęstochowa Upland is also included.

The information available on the Internet makes reference to economic objectives and states that "the Sheep Plus project" is meant to have a targeted impact on the ecological identity in the mountain regions and it is also intended to encourage to take "initiative towards ensuring the sustainable development of village areas". In other words, the project is a complex undertaking which fits into a broader conception of sustainable development. The concept of "sustainable development" which is being introduced assumes including in the overall economic calculation the broadly understood cost of intensive development which brings maximum profits to the investors. It assures that the cost concerning the natural environment as well as the impact on the local inhabitants of the region is being minimalized.

On another Internet site, where the essence of the economic-cultural programme is presented, it is assured that the "Sheep Plus project encompassing the activities in the Silesian and Żywiec Beskids is in line with the resolutions of the Carpathian Convention, which is the framework document drafting the cooperation to foster the protection and sustainable development in the Carpathian Mountains". Here the objectives of the project are described as clearly geared towards ecological and economic aims. The information provided on these website pages says that the "Sheep Plus" project together with the Carpathian Convention, "is an innovative instrument which ensures international protection of the unique natural habitat and cultural heritage located in the Carpathian region". Thus also this time the main objective is, on the one hand, the protection of the endangered natural environment, and on the other hand, the endangered local culture perceived as a part of the national heritage. In what follows 
the document points to the social and economic objectives of the project: "The convention contributes to improving the living standards of the inhabitants of the region, strengthening the local economy and increasing the social activity of the local communities". The objectives of the convention which are summed up in the official language, or rather official jargon, point to the holistic nature of the convention in a broad context: "The essence of the Framework Convention is a declaration of all the member states to mutually harmonize and agree on the policy of their individual sectors in a way which favours the overarching objective of this treaty".

In what follows the "Sheep Plus" project has become the cornerstone of the regeneration of the pastoral tradition in the Northern Carpathian Mountains, including Podhale and Ochotnica. The project also became an inspiration for the Carpathian Agreement, which received the name of "Carpathian Mountains our home". As it reads in the document available on the Internet, the Carpathian Agreement is "an open association. Its primary aim is to gather as many organizations and institutions as possible interested in the protection and sustainable development of the Carpathian region in order to preserve the cultural values and natural beauty of the mountains" Among the organizations, associations and centres which in their programmes include conservation and protection of the natural habitat and cultural identity of the Carpathian Mountains are those, which in their programmes intellectually ascribe to the ecological conception underlining multiculturalism and sustainable development.

The return of sheep farming is also supported by health and dietary arguments. Of course it is not the health benefits of grazing sheep which are considered but the qualities of the produce made in the shepherd's huts. In a special issue album devoted to sheep farming in the Carpathian region we can find an article which in a factual language - of medicine and chemistry - describes the values contained in sheep's milk and its derivative produce (various types of cheese and sheep's milk whey, a by-product in cheese making). According to Milerski, Kukuczka ${ }^{10}$ the produce has a preventative effect to protect against arteriosclerosis and diabetes. The original natural shepherd's hut method of producing sheep's cheese is highly praised as the only way to preserve their real qualities.

\section{WALLACHIAN SHEPHERDS AND HIGHLANDERS}

Today we can observe a return to the history of settlement in the Northern Carpathian Mountains, which started in the $14^{\text {th }}$ century. In this context the history of pastoral settlers, the Wallachian shepherds is seen as belonging to the same cluster concept. The Wallachian past of the Podhalan villages is brought back during local

${ }^{9}$ Owca Plus, http://www.owcaplus.pl/przykladowa-strona-owca/program-owca-plus/ [online: 2014-12-21].

${ }^{10}$ Milerski M., Kukuczka H. Owce w Beskidach - produkty i lekarstwo, [in:] Kiereś M. (ed.) Pasterstwo w Karpatach. Tradycja a wspótczesność. Szkice, (Warszawa: Centrum UNEP/GRID \& Grafikon, 2013), 171. 
conferences, gatherings and meetings also in Ochotnica, which is with pride introduced as a Podhalan village located on the Wallachian Right. According to local inhabitants, it is where the entire highland and Podhalan tradition was originally shaped together with various technical and cultural skills. The Wallachian Right granted a privileged status to settlers and without taking away their personal freedom it made them direct subjects to the Polish king. Those inhabitants of Ochotnica who bear the names of "Król" or "Królczyk" (meaning king) maintain that their names come from the past of Ochotnica and are derived from their status as direct subjects of the Polish King.

This free status was also granted to the Wallachian shepherds in other countries. In the times of the Ottoman Empire, in contrast to other people working on farms, they retained their freedom, which among other things included the right to travel and resulted in the spatial mobility of the shepherds ${ }^{11}$.

The features of character of the Carpathian shepherds are ascribed to their lifestyle and the need to adapt to harsh severe environmental conditions. In consequence their character features which stem from their pastoral occupation and care-free life of a free settler can be perceived as elements of their auto-stereotype present in the image of a highlander (Polish Góral) functioning outside their community. The specific features of the character typical of highland people are ascribed to their Wallachian roots by the highlanders themselves and by the outside researchers. These features include: strength, sense of freedom, self-reliance, endurance in hardship, fierceness, and selfdignity. The shepherds used the word hyr which in the Żywiec dialect means, pride, honour and glory ${ }^{12}$. This well established auto-stereotype among Polish highlanders may even lead to regional or regional-ethnic megalomania.

At present the knowledge about the historical development of the village is not popularized among the inhabitants of Ochotnica. It is disseminated and enriched on the basis of scientific accounts and presented as the Wallachian tradition. In a book published in 2013 devoted to the Carpathian pastoral tradition, the authors including researchers and practitioners, write that sheep grazing was brought to the Carpathian ranges by Wallachian shepherds (also called Vlachs) as a new element. While they also maintained their old archaic cultural features ${ }^{13}$, they introduced new technologies into farming which were fairly homogenous thanks to the migration of shepherds along the entire ranges of the Carpathian Mountains. In other words, the traditional Wallachian pastoralism, their cultural patterns connected with the transhumant pastoral economy gave rise to the cultural features of the Polish highlanders, but also of those from other countries. The fate of the Wallachian shepherds in the Balkan region was exceptional.

11 Kłapyta, "Piotr, Wołosi - nomadzi Bałkanów", [in:] Kiereś M. (ed.) Pasterstwo w Karpatach. Tradycja a współczesność. Szkice, Centrum UNEP/GRID \& Grafikon, Warszawa 2013, s. 34.

12 Rosiek, Barbara, Beskidzcy pasterze - osobliwości szałaśnictwa na żywiecczyźnie, [in:] Kiereś M. (ed.) Pasterstwo w Karpatach. Tradycja a współczesność. Szkice, Centrum UNEP/GRID \& Grafikon, 2013), 87.

13 Kłapyta, "Wołosi...", s. 34 
Many characteristic features which make the highland culture so distinctive have their origin precisely in the practices of the Wallachian shepherds. Today when the highlanders from Ochotnica are being informed about the Wallachian roots of their village and local customs they are also told about their origin and their Wallachian identity. This breaking news for some is sometimes shrouded in an aura of bewilderment as not all the inhabitants of Ochotnica are aware of the historical roots of their village. During the Watra celebrations [the gathering of the local community around an open fire] in August 2011 when one of the local activists of the Podhalan movement received a symbolic emblem - a Wallachian pastoral staff, it was perceived as a peculiarity. The participants of the gathering were rather surprised that they - the highlanders are called Wallachians. In a way the shaping of the local community's identity by elements of the ideology formulated at the level of European organizations is received with indifference, or even with resistance.

\section{REBIRTH OR NEW ETHNICITY/REGIONALISM}

In Ochotnica the resumption of these elements of tradition, which are still remembered by the oldest inhabitants, includes the restoration of the customs related with the movement of the sheep (Polish redyk) to the high mountain pastures and clearings. This means the return of the magical rituals connected with this event which were cultivated not long ago, and which to a certain extent have been forgotten ${ }^{14}$. The rich ceremonial rituals which are being restored are connected with the pastoral social structure, with the nature and the seasonal character of the transhumant sheep farming which involved the movement of the livestock to the mountain pastures and clearings in the spring (traditionally on St George's day) and then back to the valleys in the autumn (on St Michael's day***15). The customary celebrations were accompanied by music and dancing, mainly male dances, which in the past were full of symbolic meaning of rituals. Today although the customary celebrations are accompanied by music, its ritual symbolic sense is not understandable for the participants. In effect, the development of regionalism as an ideology leads to new phenomena, which can be analysed with the example of the transformations which have occurred in mountain folk music including all aspects: the instrumentals, melody line, rhythm and the circumstances in which it is performed. At present the implementation of the directives of the regional policy (ideology) includes the return of the relic forms of musical folklore and regional folk bands. It seems that the most important outcome of the process is the emergence of the idea of folklore as value, as it has an equal impact on the attitudes towards local highland dialects, customs and traditional (to be more precise defined and classified as traditional) elements of the material culture. These elements

14 Janicka-Krzywda, Urszula, "Magia hal i połonin”, [in:] Kiereś M. (ed.) Pasterstwo w Karpatach. Tradycja a współczesność. Szkice, Centrum UNEP/GRID \& Grafikon, Warszawa 2013, pp. 41-49.

15 Owca Plus, http://www.owcaplus.pl/losod-owiec-na-hali-boraczej/ [online: 2014-12-19]. 
become, as if before our eyes, symbols and more specifically markers of the highland culture, which in turn means key ingredients of the highlanders' identity.

In contemporary times one of the most important aspects of the folk highland culture is its commercial function. The ceremonial rituals which are reinstated are not only, or maybe not primarily, connected with emotions shared by those who perform them and their neighbours. Today the practiced ritual, for example of redyk or watra is primarily an artistic spectacle directed at the audience, which by principle includes not only the fellow members of the local community but also outsiders - the tourists. It is to their taste and patterns of the present lifestyle that the course, content, accessories, duration and the behaviour of the actors have to be adjusted. As a result of these processes new elements appear, new instruments, trademark music, only partially based on forms which are described as relic by researchers who frequently make it available to performers. From the point of view of a historian of culture, a completely new element includes girls and women playing instruments in Ochotnica (and other Podhalan villages), as this was not conceivable in the old highland tradition. Another serious transformation related to the civilizational changes concerns the place of music in people's lives, with the metaphysical and aesthetic function of mountain folk music fading away ${ }^{16}$.

The fact that the highlanders' festivals and customary rituals are, by principle, presented as spectacles to a wider public, that is as wide as possible, does not interfere with their significant impact on the cultural self-identity of the highlanders themselves. According to Anthony D. Smith ${ }^{17}$ during public events the "unique symbol of identification is presented that is the name, history and the foundation myth which has a community-bonding function".

The social structure of the shepherd's huts, which are being reinstated, only vaguely resembles the structure we read about in historical accounts of ethnographers from several decades ago. The head shepherd (Polish baca), as the superior and an authority in the hut structure should have hyr - dignity, pride, expertise and respect. Although today young head shepherds relate to these patterns and make every effort to follow them but the pastoral tradition, as local people (our informants) complain, is a part of wider social and civilizational transformations and, in effect, it has practically disappeared. In the present one has to meet the formal requirements to earn the head shepherd's licence, pass the exams and obtain qualifications.

\section{BEING A HEAD SHEPHERD IN TODAY'S OCHOTNICA}

Jarosław Buczek is the first new fully licenced head shepherd in Ochotnica Górna. Since 2012 he has dealt with sheep grazing on the clearings leased from the local highlanders, mainly in the valley of the Jamne brook. The young shepherd is a person

16 Janicka-Krzywda, "Magia...”, 68.

${ }^{17}$ Smith, Anthony D. The cultural foundations of nations: hierarchy, covenant, and republic, (New York: John Wiley \& Sons, 2008). 
who embodies the changes which took place in the lifestyle of the Ochotnica highlanders and in their culture; he is educated (a graduate of the secondary school), shows sensitivity and has a broad range of interests, while at the same time he exhibits devotion to the old customs classified as traditional. This devotion, however, is no longer habitual or instinctive because the head shepherd was not raised in a sheep farming family, although his family belongs to the long standing inhabitants of Ochotnica. The way he relates to tradition, shepherding, human-nature relationship and especially human-animal ties is reflexive. Because of his education and additional training during interviews he uses scientific language, frequently mixes mountain folk dialect with scientific terminology and expresses himself in literary language.

To illustrate, he talks about the shrinking "biodiversity", about the "extinction of certain species of plant life" related to the areas used for sheep grazing for a long time. This is known to head shepherds and they talk about it using the language of scientists ${ }^{18}$. What is more they themselves write articles, with the example of the book mentioned earlier on in this paper, entitled "The pastoral tradition of the Carpathian Mountains" ***. Today's head shepherd quotes research papers written by scientists and writes about the qualities of a head shepherd in the Carpathian tradition in the following words: "In the village of Gorce the head shepherd enjoyed respect and trust. His authority was built on his life experience and some genuine qualities". The author further continues about the sense of responsibility for the animals and people under his care. It appears that the head shepherd was "also a doctor who used herbs to treat not only his livestock". Although the author of the article describes the old pastoral customs he derives his knowledge not from oral communication but from literature from which he learned about magic protective rituals. The head shepherd writes about the 'professional secrets' which as a rule were not shared. He, among others, makes references to the work of Stanisław Poniatowski, a distinguished Polish ethnologist, murdered in a concentration camp during WWII. As he writes together with other young shepherds he had visited Romania, where he got to know the tradition. $\mathrm{He}$ further mentions a young historian, Dawid Golik, whose duty is to describe the tradition, that old inhabitants are not ashamed of but the young ones happen to be embarrassed about.

The young head shepherd is looking back and reminiscing. "The idea (that is reinstating sheep farming in Gorce) was conceived two years ago". It is then that he started to make his childhood and early teen years dreams come true. There is no doubt that the European Union projects supported and structured his original ideas. The return of sheep farming required that many conditions had to be met, which was difficult to implement by a single person. The partitioning of the land and the far reaching individualization of economic activities make initiatives aimed at the reinstatement of the old patterns of a pastoral economy difficult. That is why it requires collective effort as "nobody will manage it single handed. To specialize in sheep farming one

18 Buczek, Jarosław, "Pasterstwo w Gorcach", [in:] Kiereś M. (ed.),Pasterstwo w Karpatach. Tradycja a współczesność. Szkice, (Warszawa: Centrum UNEP/GRID \& Grafikon), 114. 
needs a minimum of 300 milking sheep. (...) and to start with, the pastures have to be prepared beforehand" (in EM 1, 2012). Our informant explains in detail the scope of the changes which have taken place on those clearings used for grazing where barren grass (psiara in the highland dialect) has spread. To remedy the situation lambs need to be pastured there because only the lambs will eat barren grass, adult sheep will not feed on it. In the case of the young flock of sheep which were brought over by the young head shepherd to the Jamne valley, lambs will only come the following year. However, when I visited the shepherd's hut in 2013-2014 there were already 300 or more sheep.

In the conversations with the young modern head shepherd several themes reappear, including degradation of the natural habitat in Gorce brought about by the demise of sheep grazing, nurturing pastoral tradition as a great value, cooperation within the village community, and cultivation of the highlanders' identity.

One of the qualities which is mentioned by Jarosław Buczek as part of the image of an ideal head shepherd/sheep-keeper is the relationship between the shepherd and the animals. On the one hand, it is perceived in practical terms connected with the economic objectives but on the other hand, it has some ethical (axiological) dimension: As he says "I am learning to respect animals". He underscores that if we expect to obtain something from an animal, we also have to give something from ourselves, including first of all our care and protection. This is what is rightly deserved by sheep, cows and dogs. A respectable attitude towards animals always pays off - that is an animal will always pay back what it has received from a man. Our informant points to the fact that once all animals were respected and cared for because the fate of people depended on their fate.

In the pastoral economy of the Wallachian type, cheese was the staple diet of people and therefore the saying that in their daily prayer "Our Father", the Wallachians used to say "give us our daily cheese" is only to some extent humorous, as it was not bread but cheese that they ate on an everyday basis. "This was the way people used to live in the mountains" (in EN1, 2013). When asked what he sees as the most important that should be preserved, the head shepherd says that it is "the highlanders' sense of identity and the highlanders' customs". He reminds that there used to be "some rituals performed, for example in the spring, blessing ceremonies, prayers" and they should be necessarily reinstated. In his job as the head shepherd he wants to reintroduce these elements of behaviour, which are now treated by everybody, not only by himself, as belonging to the past. He speaks about the need to preserve the regional/ethnic identity of the highlanders and he laments that some young people are not able to say that they are highlanders and explain why. As the most difficult task he regards the reinstatement of the Wallachian tradition of the highlanders and adapting it to the new conditions, to civilization. Among the necessary changes, a change in the social relations within the village community will be the hardest to achieve. "The most important thing is for the people to start again to work together, to think together and act for the common good. The worst thing now is that people are so divided" (w 1, EN 2012). This is how the young head shepherd builds his conception of "the return to the tradi- 
tion" which involves a regeneration of traditional Wallachian sheep farming in the village of Ochotnica Górna. He is doing it by reaching for scientific accounts and not by relying on the tradition mechanically passed down from generation to generation.

\section{CONCLUSIONS}

Paweł Schmidt when writing about tradition in Ochotnica thanked his informants saying that "they made it possible to show to my students that the world I teach them about and that I remember from my childhood really exists and thanks to them it can be still experienced"19. The anthropologist seems to assume that in Ochotnica what used to exist at the time of his childhood still "really" exists, that is to say the "traditional" highland culture continues to be observed. In this article I wanted to take a reflective look at what "truly" exists in Ochotnica and what the truth refers to. The methodological remarks made by Paul Rabinow concerning the complexity of the material collected in field research seemed relevant to my work. Another conception which I found convenient and accurate was the notion of "invented tradition" put forward by Eric Hobsbawm. As practiced by anthropologists my intention was to infiltrate the ethnic world of my informants and get to know their conceptualisations referring to the pastoral tradition which include meaning structures, hidden hierarchies of importance and choices, and which are present in the mentality of the contemporary inhabitants of Ochotnica Górna. When investigating the contemporary processes taking place in the highland culture, it seems especially interesting to connect the concept of tradition with social acceptance, including the enthusiasm of some members of the community and the more or less unwelcoming indifference of others.

The reconstruction of shepherds' huts (to be precise building them from scratch), creating tourist trails which have the word "Wallachian" in their name, in a way means reinstating the Wallachian ethnic community "from the top" by pointing out the Wallachian cultural roots to the members of the highland communities. In this way the Wallachian quality becomes an emblem, a sign of identity or a symbol of the community lost in the passage of time, and of a mixed tradition.

${ }^{19}$ Schmidt P., Tradycja i jej (re)konstrukcje a atrakcyjność turystyczna świata lokalnego. Przykład Ochotnicy, (in:) E. Jagiełło, P. Schmidt (red.), Kultura i rynek. Interdyscyplinarne szkice humanistyczne, (Lublin: E-naukowiec, 2013), 29. 
